\title{
PENGEMBANGAN MEDIA PEMBELAJARAN BERBASIS SPARKOL VIDEOSCRIBE YANG DIINTEGRASIKAN DENGAN WONDERSHARE FILMORA PADA MATA PELAJARAN GEOGRAFI MATERI MITIGASI BENCANA ALAM
}

\author{
Yunita Bouato ${ }^{a}$, Fitryane Lihawa ${ }^{\text {b }}$, Rusiyah Rusiyah ${ }^{\mathrm{c}}$ \\ ${ }^{a}$ Universitas Negeri Gorontalo, Jl.Prof. Dr Ing BJ Habibie, Kabupaten Bone Bolango 96119, Indonesia \\ ${ }^{b}$ Universitas Negeri Gorontalo, Jl.Prof. Dr Ing BJ Habibie, Kabupaten Bone Bolango 96119, Indonesia \\ ${ }^{c}$ Universitas Negeri Gorontalo, Jl.Prof. Dr Ing BJ Habibie, Kabupaten Bone Bolango 96119, Indonesia
}

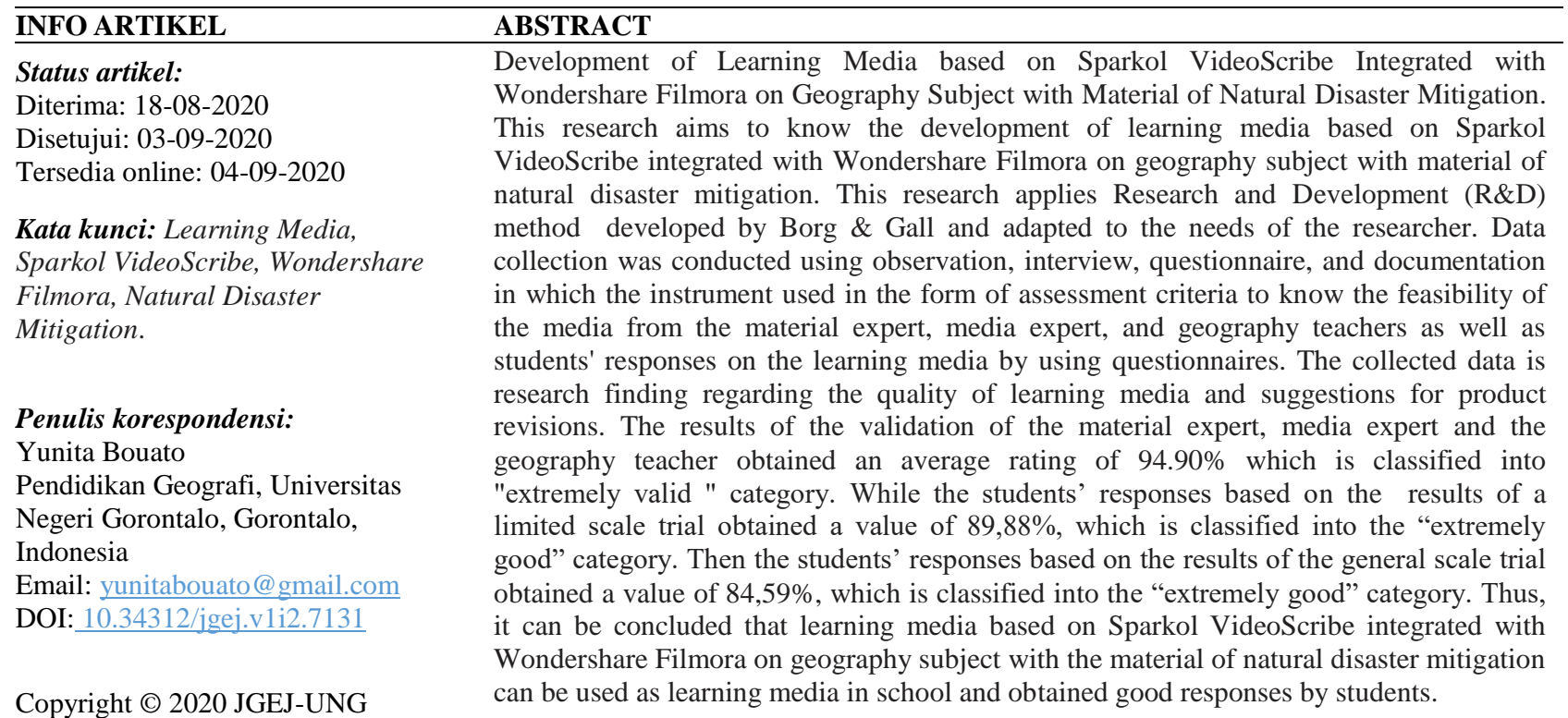

All Rights Reserved.

\begin{abstract}
ABSTRAK
Penelitian ini bertujuan untuk mengetahui pengembangan media pembelajaran berbasis Sparkol VideoScribe yang diintegrasikan dengan Wondershare Filmora pada materi mitigasi bencana alam. Metode yang digunakan dalam penelitian ini yaitu menggunakan metode (Research and developmen /R\&D) yang dikembangkan oleh Borg \& Gall. Teknik pengumpulan data melalui observasi, wawancara, angket, dan dokumentasi. Instrumen yang digunakan berupa kriteria penilaian untuk mengetahui kelayakan media dari ahli materi, ahli media, dan guru geografi serta respon siswa terhadap media pembelajaran dengan menggunakan angket. Data yang dikumpulkan berupa hasil penelitian mengenai kualitas media pembelajaran serta saran untuk revisi produk. Hasil dari validasi ahli materi, ahli media dan guru geografi mendapatkan nilai rata-rata 94,90\% dengan tingkat kevalidan masuk dalam kualifikasi "sangat valid", sendangkan untuk respon siswa dari hasil uji coba skala terbatas mendapatkan nilai $89,88 \%$, nilai ini masuk dalam kategori "sangat setuju", kemudian respon siswa dari hasil uji coba skala general mendapatkan nilai 84,59\% nilai ini masuk dalam kategori "sangat setuju", dengan demikian media pembelajaran berbasis Sparkol VideoScribe yang diintegrasikan dengan Wondershare Filmora pada materi mitigasi bencana alam dapat digunakan sebagai media pembelajaran di sekolah dan mendapat respon yang sangat baik oleh siswa.
\end{abstract}




\section{Pendahuluan}

Pendidikan adalah bagian yang sangat penting dalam kehidupan manusia. Pendidikan nasional termuat dalam pasal 3 UU No.20 tentang pengembangan manusia yang beriman dan bertakwa kepada Tuhan Yang Maha Esa, berakhlak mulia, sehat, berilmu, cakap, kreatif, mandiri, dan menjadi warga Negara demokratis serta bertanggung jawab (Pendidikan, 2007). Kemajuan dibidang Teknologi Informasi dan Komunikasi (TIK) sudah sedemikian pesat dan telah banyak membantu berbagai aktivitas manusia. Kemajuan dalam bidang teknologi informasi dan komunikasi dapat dimanfaatkan dalam dunia pendidikan, ada banyak alternatif pembelajaran yang bisa dimunculkan dari pemanfaatan teknologi ini. (Irwandani \& Juariah, 2016). Keberhasilan pembelajaran tersebut dapat ditinjau dari proses pembelajaran yang dirancang dan dijalankan secara professional oleh pendidik (Ikbal, 2012). Pendidik dapat memanfaatkan Teknologi Informasi dan Komuniksi (TIK), khususnya komputer dan internet dalam membantu proses pembelajaran di dunia pendidikan (Pratiwi et al., 2019).

Pada kenyataanya, media pembelajaran yang digunakan oleh guru belum sepenuhnya memanfaatkan teknologi. Hal ini dikarenakan guru tidak memiliki cukup kemampuan, dalam membuat media pembelajaran yang lebih inovatif berbasis teknologi. Ditambah lagi dengan keterbatasan waktu, yang dimiliki guru dalam membuat media pembelajaran. Peserta didik juga memberikan informasi, bahwa dalam pembelajaran mereka sering menggunakan buku cetak, sehingganya mereka sulit dalam memahami ataupun mengingat materi yang bersifat abstrak yang diajarkan guru. Berdasarkan permasalahanpermasalahan tersebut, maka perlunya pengembangan media pembelajaran yang menarik dan mudah dimengerti oleh siswa. Diharapkan dengan pengembangan media pembelajaran berupa video dapat mengatasi kesulitan yang dihadapi peserta didik dalam belajar.

Video merupakan media penyampaian pesan termasuk media audio-visual atau media pandang dengar. Peranan media video pembelajaran sebagai berikut: (a) Dapat menarik perhatian peserta didik sehingga dapat menumbuhkan motivasi belajar. (b) Memperjelas makna bahan pengajaran sehingga mudah dipahami. (c) Metode pengajaran lebih bervariasi. Siswa lebih banyak melakukan kegiatan belajar (Diani et al., 2016). Hal ini sejalan dengan (Darwanto, 2007) Penggunaan media audio visual sebagai media pembelajaran yang ditujukan untuk meningkatkan efektivitas dan efisiensi proses belajar mengajar diharapkan mampu mengembangkan daya nalar para siswa. Salah satu aplikasi atau software untuk membuat media pembelajaran berupa video yaitu Sparkol VideoScribe dan Wondershare filmora.

Menurut (Dyah, 2018) Sparkol Videoscribe merupakan sebuah media pembelajaran video animasi yang terdiri dari rangkain gambar yang disusun menjadi sebuah video utuh, dengan karakteristik yang unik, Sparkol VideoScribe mampu menyajikan konten pembelajaran dengan memadukan gambar, suara, dan desain yang menarik sehingga siswa mampu menikmati proses pembelajaran. Merujuk penelitian dari (Chun, 2013) Sparkol VideoScrie merupakan salah satu software yang digunakan untuk membuat media pembelajaran, yang berupa video. Sparkol VideoScribe merupakan alat/tool yang sangat efektif dalam menjelaskan konsep-konsep rumit menjadi lebih menarik dan menyenangkan. Menurut (Air et al., 2015) Menggunakan Software Sparkol VideoScribe dapat lebih meningkatkan pemahaman karena tidak hanya melibatkan visual tetapi juga audio.

Sparkol VideoScribe memiliki kelebihan yaitu dapat membuat sebuah animasi dengan menggabungkan gambar, teks, gerakan tangan, dan suara dalam bentuk video, namun disamping kelebihannya Sparkol VideoScribe memiliki kekurangan yaitu tidak dapat melalukan editting video seperti menggabungkan beberapa video menjadi satu video, memotong video dan lain-lain sehingganya untuk membuat sebuah media pembelajaran yang menarik dibutuhkan software yang lain yang dapat digunakan untuk mengedit video. Salah satu aplikasi yang software dapat mengedit video adalah Wondershare Filmora. Software Wondershare Filmora merupakan sebuah aplikasi untuk membuat dan mengedit video baik berupa kumpulan gambar, maupun gabungan dari beberapa video menjadi sebuah video baru yang berkualitas, Wondershare Filmora juga digunakan untuk editting video dengan menggunakan effect, transition, dan elements sehingga membuat media pembelajaran lebih menarik.

Adanya media pembelajaran berbasis Sparkol VideoScribe yang diintegrasikan dengan Wondershare Filmora dapat menjadikan proses pembelajaran menjadi lebih efektif dan menyenangkan untuk siswa. Hal ini sesuai dengan beberapa penelitian sebelumnya menggunakan software Sparkol Videoscribe pengembangan media audio visual berbasis Sparkol VideoScribe sangat efektif dalam meningkatkan hasil belajar mahasiswa (Dilla, 2016). Penelitian ini juga pernah dilakukan oleh ( Dyah Ayu Wulandari, 2016) dengan menggunakan Sparkol VideoScribe memperoleh hasil media pembelajaran Sparkol 
VideoScribe layak untuk dijadikan media pedukung pembelajaran dalam kelas dan mampu meningkatkan minat belajar siswa pada mata pelajaran IPA.

\section{Metode}

Lokasi yang dijadikan uji coba yaitu di SMAN 3 Kota Gorontalo yang terletak di Jln. Achmad Nadjamuddin, Kelurahan Limba U Dua, Kecamatan Kota Gorontalo Selatan, Provinsi Gorontalo. Uji coba pengembangan ini dilakukan di kelas XI IPS 3 dan 4 dengan jumlah siswa yang hadir yaitu 21 siswa untuk kelas XI IPS 3 dan 30 siswa kelas XI IPS 4 selain itu produk pada pengembangan ini sebelum di ujidi validasi oleh ahli materi, ahli media dan guru geografi. Penelitian ini dilaksanakan selama 5 bulan dari bulan September, Oktober, November, Desember, dan Januari. Objek penelitian pengembangan media ini adalah aplikasi Sparkol VideoScribe yang diintegrasikan dengan Aplikasi Wondershare Filmora yang marupakan aplikasi untuk editting video.

\subsection{Prosedur Pengembangan}

Penelitian ini menggunakan metode penelitian dan pengembangan (Research and developmen /R\&D) Borg \& Gall, Alasan memilih metode ini adalah, yaitu : (1) Metode R\&D dipandang tepat untuk mengembangkan media pembelajaran karena memiliki langkah-langkah kerja yang sistematis dan sesuai dengan kebutuhan nyata disekolah, (2) Metode R\&D pada setiap langkah yang akan dilalui selalu mengacu pada hasil langkah sebelumnya sehingga pada akhirnya diperoleh suatu produk media pembelajaran yang baru.

Adapun tahapan dalam metode penelitian R\&D ini sebagai berikut : (1) Tahapan pengumpulan data, (2) Tahapan Perancangan, (3) Tahapan Pengembangan Produk, (4) Uji coba tahap awal, (5) Revisi hasil validasi, (6) Uji coba skala terbatas, (7) Penyempurnaan Produk uji lapangan skala terbatas, (8) Uji coba lapangan skala general, (9) Revisi produk akhir.

\subsection{Metode Pengumpulan Data}

Metode pengumpulan data yang digunakan dalam penelitian ini yaitu observasi dengan mengamati secara langsung sarana dan prasarana penunjang pembelajaran disekolah, perangkat belajar serta perilaku peserta didik, wawancara digunakan untuk pengumpulan data ketika melakukan studi pendahuluan, dan angket untuk memperoleh data tentang pendapat responden validator ahli dan siswa berkaitan dengan pengembangan media pembelajaran geografi berbasis Sparkol VideoScribe yang diintegrasikan dengan Wondershare Filmora. Angket yang disediakan oleh peneliti berupa angket validasi ahli dan angket respon siswa.

\subsection{Teknik Analisis Data}

Analisis data hasil validasi dari tim ahli baik dari ahli materi, ahli media, dan ahli guru geografi dianalisis secara deskripsi kualitatif. Langkah pertama dengan memberikan skor pada tiap kriteria Penilaian terdiri dari 5 penilaian skor (Sukardi, 2014:146), yaitu :

$$
\begin{aligned}
& 5=\text { Sangat baik/Sangat layak } \\
& 4=\text { Baik/Layak } \\
& 3=\text { Cukup baik/Cukup layak } \\
& 2=\text { Tidak baik/Kurang layak } \\
& 1=\text { Tidak ada/Tidak layak }
\end{aligned}
$$

Selanjutnya, dilakukan perhitungan kriteria kevalidan media pembelajaran geografi yang dikembangkan: Untuk menentukan presentase hasil data tersebut, maka digunakan rumus peresentase yang dikemukakan oleh (B.Subal et al., 2010)

Hasil yang nantinya akan diperoleh dari perhitungan persentase, selanjutnya ditentukan tingkat kelayakan produk hasil pengembangan. Pemberian tingkat kelayakan produk menggunakan kualifikasi yang mempunyai kriteria pada tabel 1 : 
Tabel 1. Kualifikasi Tingkat Kelayakan (B.Subali et al., 2010)

\begin{tabular}{ccc}
\hline Persentase & Kualifikasi & $\begin{array}{c}\text { Kriteria } \\
\text { Kelayakan }\end{array}$ \\
\hline $84 \%<$ skor $\leq 100 \%$ & Sangat valid & Tidak Revisi \\
\hline $68 \%<$ skor $\leq 84 \%$ & Valid & Tidak Revisi \\
\hline $52 \%<$ skor $\leq 68 \%$ & Cukup valid & Perlu Revisi \\
\hline $36 \%<$ skor $\leq 52 \%$ & Kurang valid & Revisi \\
\hline $20 \%<$ skor $\leq 36 \%$ & $\begin{array}{c}\text { Sangat Kurang } \\
\text { valid }\end{array}$ & Revisi \\
&
\end{tabular}

Analisis data respon siswa dengan cara deskripsi kuantitatif dengan menggunakan teknik persentase yang dikemukakan (Sugiyono, 2015).

\section{Hasil dan Pembahasan}

Pengembangan media ini dalam proses pembuatan dilaksanakan secara bertahap yang disesuaikan dengan metode penelitian dan pengembangan R\&D yang dikembangkan oleh Borg \& Gall, dan untuk menghasilkan media pembelajaran yang layak, dilakukan serangkaian validasi oleh ahli materi, validasi ahli media, Validasi guru geografi, uji coba skala terbatas dan uji coba skala general. Semua rangkaian tersebut dimaksudkan untuk memperoleh data yang selanjutnya dilakukan revisi atau perbaikan agar tercapai media pembelajaran yang baik dan bermanfaat bagi penggunannya.

Penelitian dan pengembangan ini menghasilkan sebuah produk berupa video dengan format mp4. Video pembelajaran ini berisikan materi mitigasi bencana alam yang dibuat dengan animasi-animasi yang menarik dan mudah untuk dipahami, video ini juga diiringi dengan musik dan voice over di setiap tampilan sehingga dapat menambah semangat siswa dalam belajar, selain itu video pembelajaran ini dilengkapi dengan kegiatan evaluasi disetiap materi pembelajaran sehingga siswa tidak hanya memahami materi akan tetapi dituntun untuk berfikir kritis, dan dapat memecahkan masalah baik secara individu maupun bersama dengan kelompok, dan dapat membantu guru untuk mengetahui hasil belajar siswa dari kegiatan evaluasi tersebut.

\section{a. Tayangan Pembuka}

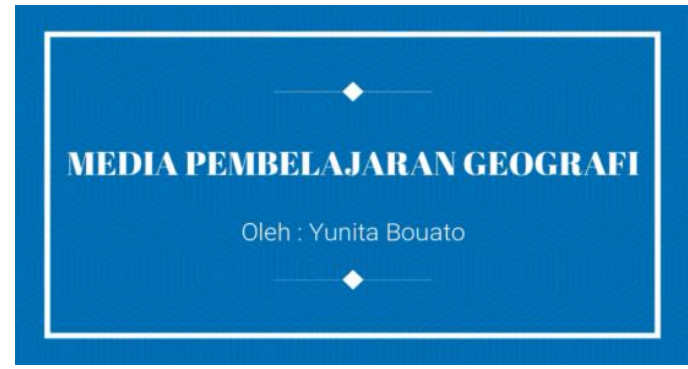

(a) Tayangan Pembuka 1

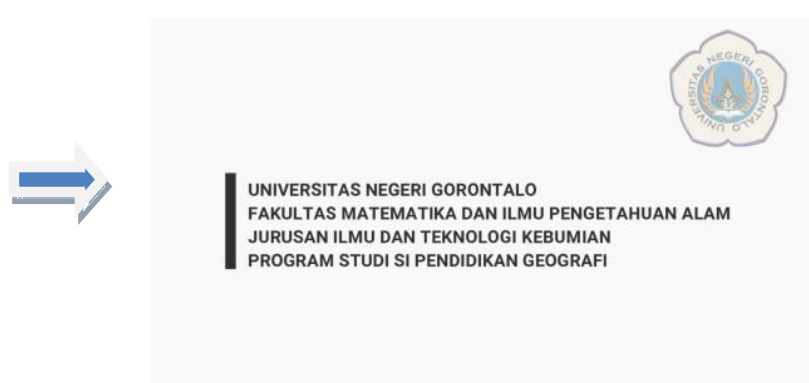

(b) Tayangan pembuka 2

\section{Gambar 1. Tayangan Pembuka}

Pada tampilan pembuka ini terdapat teks media pembelajaran geografi, nama pembuat, Universitas Negeri Gorontalo, Fakultas Matematika dan Ilmu Pengetahuan Alam, Jurusan Ilmu dan Teknologi Kebumian, Program Studi Pendidikan Geografi, pada tampilan pembuka juga diringi dengan musik pengiring atau backsound yang dapat menambah semangat siswa untuk terus menonton video pembelajaran ini. 
b. Tampilan judul

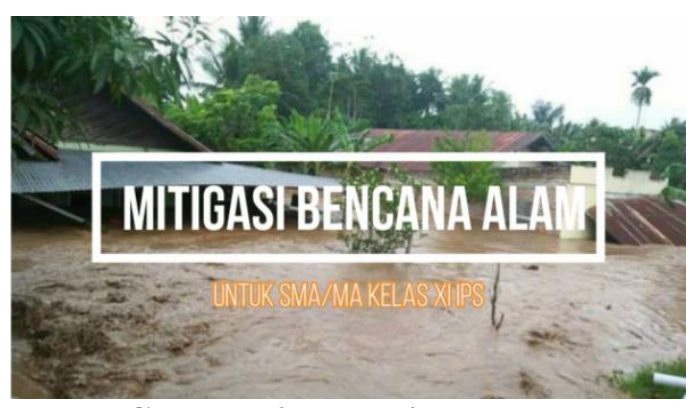

Gambar 2. Tampilan Judul

Pada tampilan judul terdapat background gambar yang sesuai dengan materi yang akan dipelajari, dan terdapat juga teks mitigasi bencana alam, dan penggunaan media untuk SMA/MA kelas XI IPS, kemudian pada tampilan judul berikutnya terdapat juga kalimat Assalamu'alaikum warahmatullahi wabarkatu, salam sejahtera bagi kita semua yang diiringi dengan voice over pembuat video dan juga terdapat judul materi yang akan dipelajari pada tiap pertemuan.

c. Tampilan Kompetensi

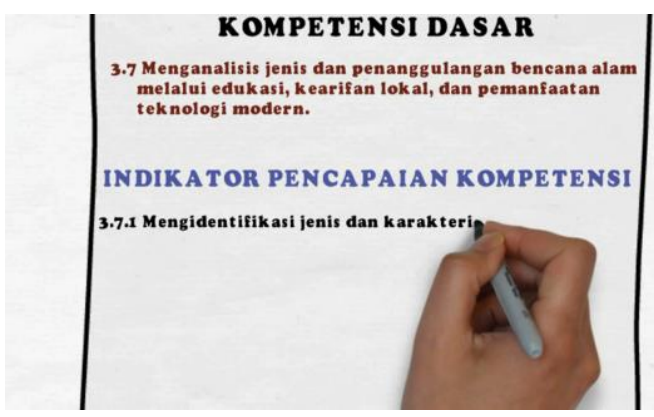

Gambar 3. Tampilan Kompetensi

Pada tempilan kompetensi terdapat teks kompetensi dasar, indikator pencapaian kompetensi dan tujuan pembelajaran. Pada kompetensi dasar berisi tentang kompetensi yang harus dicapai dalam pembelajaran mitigasi bencana alam, kompetensi dasar tersebut terdiri dari keterampilan dan pengetahuan, kemudian terdapat juga Indikator pencapaian kompetensi, pada indikator pencapaian kompetensi berisi tentang indikator yang harus dicapai pada pembelajaran mitigasi bencana alam, dan pada tampilan kompetensi juga terdapat tujuan pembelajaran yang harus dicapai pada pembelajaran materi mitigasi bencana alam.

d. Tampilan isi materi

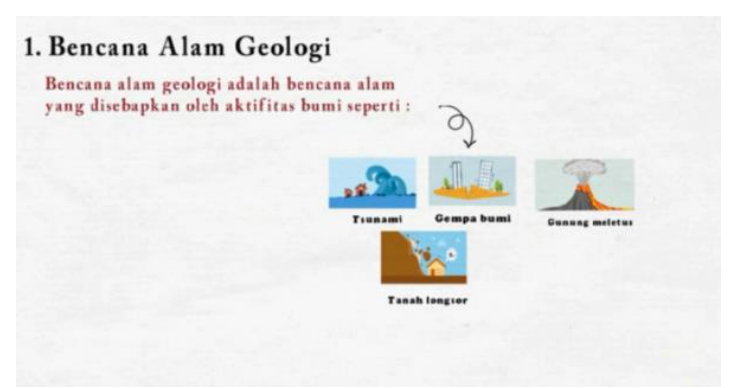

Contoh 4. Contoh Isi Materi

Pada tampilan isi materi terdapat teks, dan contoh-contoh gambar dan video mengenai materi mitigasi bencana alam. Contoh gambar dan video yang disajikan disesuaikan dengan kehidupan sehari-hari sehingga, menambah ketertarikan siswa mengenai materi mitigasi bencana alam, pada tampilan ini juga terdapat voice over yang diiringi dengan bacsound yang secara otomatis berputar sesuai dengan materi yang ditampilkan, sehingga penyampaian materi bukan hanya dari contoh gambar akan tetapi juga 
dijelaskan menggunakan voice over, hal ini dilakukan untuk memudahkan siswa dalam memahami materi mitigasi bencana alam.

e. Tampilan Kegiatan Evaluasi

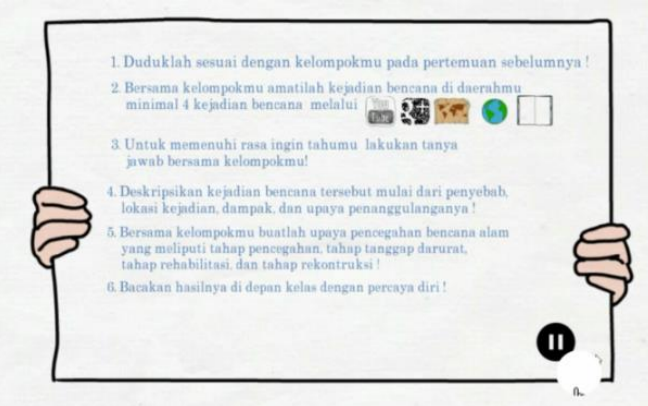

Gambar 5. Tampilan Kegiatan Evaluasi

Pada tampilan kegiatan evaluasi terdapat langkah-langkah pembelajaran yang di sesuaikan dengan tujuan pembelajaran yang akan dicapai. Sehingga siswa tidak hanya dengan memahami materi akan tetapi dituntun untuk berfikir kritis, dapat memecahkan masalah bersama dengan kelompok, dan dapat melatih kepercayaan diri dalam presentasi. Pada kegiatan evaluasi, guru dapat menilai perilaku siswa dari keaktifan dalam pengerjaan kegiatan, kemudian guru juga dapat menilai pengetahuan siswa dari hasil jawaban kegiatan evaluasi dan guru dapat menilai hasil belajar siswa dan keterampilan siswa dari cara siswa mempresentasikan hasil kegiatan evaluasi.

\subsection{Uji Coba Tahap Awal}

Setelah selesai media pembelajaran berbasis Sparkol VideoScribe yang diintegrasikan dengan Wondershare Filmora pada materi mitigasi bencana alam, kemudian dilakukan uji coba tahap awal. Uji coba ini dilakukan dengan dua tahap. Tahap pertama yaitu validasi media pembelajaran pada ahli materi dan ahli media, kemudian tahap kedua validasi media pembelajaran pada guru geografi.

1. Validasi Ahli Materi/isi

Validasi ahli materi digunakan untuk mengetahui aspek isi materi seperti, cakupan materi, kesesuaian materi dengan standar kompetensi, kejelasan isi materi, sistematika penyajian materi dan evaluasi. Hasil validasi oleh ahli materi/isi media pembelajaran suda baik, namun untuk mendapatkan hasil media pembelajaran yang lebih baik, maka perbaikan perlu dilakukan atas dasar saran/komentar dari ahli materi. Adapun saran/kometar dari ahli materi yaitu, tambahkan kegiatan evaluasi untuk dapat mengetahui sejauh mana pemahaman siswa terhadap media pembelajaran yang digunakan.

2. Validasi Ahli Media

Validasi media digunakan untuk mengetahui kualitas video seperti, kualitas tampilan, kualitas suara, kualitas ilustrasi, kualitas bahasa, dan kemudahan penggunaan media. Hasil validasi oleh ahli media masih terdapat kekurangan pada tampilan media pembelajaran, sehingga untuk mendapatkan hasil media pembelajaran yang lebih baik, maka perbaikan tetap dilakukan atas dasar saran/komentar dari ahli media. Perbaikan dilakukan berdasarkan saran/komentar ahli media yaitu :

a. Tambahkan teks dalam setiap Voice Over agar lebih memudahkan siswa untuk memahami materi

b. Sertakan sumber video dan gambar agar tidak plagiat

c. Ganti gambar yang kabur atau yang tidak jelas

d. Tambahkan ilustrasi gambar pada prinsip-prinsip penanggulangan bencana alam agar siswa lebih mudah mengingat materi

e. Tambahkan gambar Undang-undang jika materi itu diambil dari undang-undang

f. Musik dalam video divariasikan

\section{Validasi Guru Geografi}

Setelah uji coba tahap pertama selesai dilanjutkan dengan uji coba tahap kedua yaitu validasi oleh guru geografi, validasi guru geografi digunakan untuk mengetahui kesesuaian materi dengan standar kompetensi, kejelasan isi materi, sistematika penyajian materi, kualitas video, kualitas bahasa, dan kemudahan penggunaan media. Validasi oleh guru geografi tidak ada komentar ataupun saran, sehingga 
media sudah dapat digunakan untuk uji coba selanjutnya. Dari hasil validasi ahli materi dan ahli media masih terdapat kekurangan pada kegiatan evaluasi dan tampilan video sehingga perlu perbaikan pada isi materi dan tampilan video berdasarkan saran yang diberikan oleh validator, adapun hasil validasi oleh para ahli setelah media pembelajaran direvisi dapat dilihat pada tabel dibawah ini.

Tabel 3. Rekapitulasi Hasil Validasi Ahli

\begin{tabular}{rlrl}
\hline No & Validasi & Presentase $(\%)$ & Keterangan \\
\hline 1 & Ahli Materi & $96,36 \%$ & Sangat Valid \\
\hline 2 & Ahli Media & $91,66 \%$ & Sangat Valid \\
\hline 3 & Guru Geografi & $96,67 \%$ & Sangat Valid \\
\hline & Jumlah & $284,69 \%$ & \\
\hline & Rata-Rata & $94,90 \%$ & Sangat Valid \\
\hline
\end{tabular}

Tabel 3 menunjukan bahwa hasil rekapitulasi validasi terhadap media pembelajaran berbasis Sparkol VideoScribe mendapatkan nilai rata-rata $94,90 \%$ nilai ini menunjukan bahwa media pembelajaran berbasis Sparkol VideoScribe sangat valid sehingga dapat digunakan sebagai media pembelajaran dalam pembelajaran geografi khususnya materi mitigasi bencana alam.

\subsection{Uji Coba Skala Terbatas dan General}

Setelah media pembelajaran divalidasi oleh ahli materi, ahli media dan guru geografi, maka media pembelajaran berbasis Sparkol VideoScribe ini dapat diuji cobakan terhadap siswa. Uji coba skala terbatas dan uji coba skala general ini dilakukan di SMAN 3 Kota Gorontalo, yaitu pada Kelas XI IPS 3 untuk uji coba skala terbatas dengan jumlah siswa yang hadir yaitu 21 siswa dan Kelas XI IPS 4 untuk uji coba skala general dengan jumlah siswa yang hadir yaitu 30 siswa. Tujuan uji coba skala terbatas dan uji coba skala general ini dilakukan untuk mengetahui respon siswa terhadap kemenarikan media pembelajaran, kemudahan memamahi materi, dan bahasa yang digunakan dalam media pembelajaran ini. Berikut ini rekapitulasi hasil respon siswa.

Tabel 4. Rekapitulasi Respon Siswa

\begin{tabular}{cccc}
\hline No & Respon Siswa & Presentase (\%) & Kategori \\
\hline 1 & Uji Coba Skala Terbatas & $89,88 \%$ & Sangat Setuju/Sangat Baik \\
\hline 2 & Uji Coba Skala General & $84,59 \%$ & Sangat Setuju/Sangat Baik \\
\hline
\end{tabular}

Berdasarkan hasil respon siswa terhadap media pembelajaran ini mendapatkan nilai persentase sebesar 89,88\%" dan uji coba skala general mendapatkan nilai persentase sebesar $84,59 \%$ nilai ini menunjukan bahwa media pembelajaran berbasis Sparkol VideoScribe mendapatkan respon yang sangat baik oleh siswa setelah menggunakan media pembelajaran ini. Menurut (Dyah, 2018) Dengan karakteristik yang unik, Sparkol VideoScribe mampu menyajikan konten pembelajaran dengan memadukan gambar, suara, dan desain yang menarik sehingga siswa mampu menikmati proses pembelajaran. Fitur yang disediakan oleh software ini sangat beragam sehingga mampu menjadi media pembelajaran yang dapat disesuaikan dengan mata pelajaran yang diinginkan.

Media Pembelajaran berbasis Sparkol VideoScribe yang telah dikembangkan ini memiliki manfaat yaitu memudahkan siswa dalam memahami materi khusunya materi mitigasi bencana alam karena media ini dibuat dengan animasi-animasi yang mudah dipahami dengan memberikan contoh-contoh yang terjadi di kehidupan sehari-hari, media pembelajaran berbasis Sparkol VideoScribe ini juga dapat memotivasi dan menambah semangat siswa dalam pembelajaran karena media pembelajaran ini dilengkapi dengan musik dan voice over disetiap tampilan video, selain itu media ini dapat digunakan siswa belajar secara mandiri dirumah karena media pembelajaran ini dapat ditonton menggunakan smartphone siswa. Selain memiliki manfaat media ini juga memiliki kekurangan yaitu media pembelajaran berbasis Sparkol VideoScribe ini dapat digunakan di sekolah apabila terdapat listri, komputer, LCD,dan spiker. Apabila hanya digunakan secara mandiri atau individual media pembelajaran ini dapat digunakan apabila terdapat smartphone. 


\section{Kesimpulan}

Berdasarkan hasil validasi media pembelajaran oleh ahli materi, ahli media, dan guru geografi mendapatkan nilai persentase rata-rata 94,90\% nilai ini masuk dalam kualifikasi "sangat valid". Respon siswa dari hasil uji coba skala terbatas mendapatkan nilai persentase rata-rata $89,88 \%$ nilai ini masuk dalam kategori "sangat setuju". Respon siswa dari hasil uji coba skala general mendapatkan nilai persentase rata-rata sebesar $84,59 \%$ nilai ini masuk dalam kategori "sangat setuju", sehingga dapat disimpulkan bahwa media pembelajaran berbasis Sparkol Videoscribe yang diintegrasikan dengan Wondershare Filmora pada materi mitigasi bencana alam, sudah dapat digunakan sebagai media pembelajaran di sekolah dan mendapatkan respon yang sangat baik dari siswa.

\section{Ucapan Terima Kasih}

Penulis mengucapkan banyak terima kasih kepada Kepala Sekolah SMAN 3 Kota Gorontalo yang telah memberikan izin melakukan uji coba penggunaan media pembelajaran kepada siswa. Ucapan terima kasih juga yang sebesar-besarnya kepada Bapak dan Ibu Dosen Pembimbing yang telah memberikan dukungan, arahan dan bimbingan sehingga hambatan dan kesulitan dapat peneliti selesaikan dan juga terimakasih untuk kedua orang tua saya dan kaka saya yang telah memberikan dukungan baik materil maupun moril.

\section{Referensi}

Aini A S. 2018. Pengembangan Media Pembelajaran Sparkol VideoScribe Pada Materi Transportasi (Program Linear) Untuk Mahasiswa Matematika UIN . Skripsi. Universitas Islam Negeri Raden Intan Lampung

Air, Jon, Eric Oakland and Chipp Walters. 2015. The Secrets Behind The Rise of Video Scribing. UK: Sparkol Books

Asnawir, Basyirudin Usman. 2002. Media Pembelajaran. Jakarta: Ciputat Press

Chun, Yi-Min. 2013. Newsletter: office of Integrated Medical Education (5th ed). University of Toronto.

Darwanto. 2007. Televisi Sebagai Media Pendidikan. Yogyakarta: Pustaka Pelajar.

Diani, R., Yuberti, Y., \& Syafitri, S. (2016). Uji Effect Size Model Pembelajaran Scramble dengan Media Video terhadap Hasil Belajar Fisika Peserta Didik Kelas X MAN 1 Pesisir Barat. Jurnal Ilmiah Pendidikan Fisika AlBiRuNi 05, 5(2). Doi: https://doi.org/10.24042/jpifalbiruni.v5i2.126

Dyah, Ayu, Wulandari. 2016. Pengembangan Media Pembelajaran Menggunakan Sparkol Videoscribe Dalam Meningkatkan Minat Belajar Siswa Pada Mata Pelajaran Ipa Materi Cahaya Kelas VIII Di SMP Negeri 01 Kerjo Tahun Ajaran 2015/2016. Skripsi. Univesitas Negeri Semarang.

Irwandani, I., \& Juariah, S. (2016). Pengembangan Media Pembelajaran Berupa Komik Fisika Berbantuan Sosial Media Instagram Sebagai Alternatif Pembelajaran. Jurnal Ilmiah Pendidikan Fisika Al-BiRuNi 05, 5(April), 33-42. Doi:https://doi.org/10.24042/jpifalbiruni.v5i1.103

Listiani I N. 2017. Pengembangan Media Pembeajaran Video Berbasis Sparko VideoScribe Pada Materi Pokok Archaebacteria Dan Eubacteria Untuk Siswa Kelas X SMA/MA. Skripsi. Univeristas Islam Negeri Sunan Kalijaga.

Munir. 2012. Multimedia Konsep \& Aplikasi dalam Pendidikan. Bandung: Alfabeta

Musdayat I. 2015. Pengembangan Media Pembelajaran Berbasis VideoSribe Untuk Peningkatan Hasil Belajar Pada Mata Pelajaran Sosiologi Keas X MAN Bangi. Skripsi. Universitas Islam Negeri Maulana Malik Ibrahim Malang.

Pendidikan, Departemen, Nasional RI, (Undang-Undang Republik Indonesia) Penyusun, Tim, Diknas RI. (2007). Undang-Undang Republik Indonesia No 20 Tahun 2003 Tentang Sistem Pendidikan Nasional. Bandung: Penerbit Citra Umbara.

Pratiwi Dwi erlia, Latifah Sri, dan Mustari Mukarramah. 2019. Pengembangan Media Pembelajaran Fisika Menggunakan Sparkol Videoscribe. Journal of Science and Mathematics Education. 02 (3) (2019) 303-309. Doi : 10.24042/ijsme.v2i3.4355

Safitri D. 2018. Pengembangan Media Pebelajaran Berbasis Sparko VideoScribe Pada Materi Aksara Lampung Kelas III Jenjang MI/SD. Skripsi. Universitas Islam Negeri Raden Intan Lampung. 
Subali, B. 2010. Penilaian, Evaluasi, dan Ramedial Pembelajaran. Universitas Negeri Yogyakarata. Yogyakarta. $66 \mathrm{hlm}$

Sugiyono. 2015. Metode Penelitian dan Pengembangan (Research and Development). Bandung: Alfabeta.

Taum A. 2017. Pengembangan Media Pembelajaran Menulis Cerita Pendek Berbasis Multimedia VideoScribe Untuk Kelas XI IPA SMA Negeri 3 Kupang. Skripsi. Universitas Sanata Dharma Yogyakarta. 